\title{
RAZÓN NATURAL Y DEFENSA DE LA COSTA. LOS FUNDAMENTOS DEL GOBIERNO MILITAR DEL REINO DE VALENCIA EN EL REINADO DE FELIPE II
}

\author{
Juan Francisco Pardo Molero \\ Universitat de València
}

\begin{abstract}
Resumen. En el siglo xvi la difusión de innovaciones militares alteró la administración de la defensa de los reinos mediterráneos de la Monarquía Hispánica, en particular del reino de Valencia. Pero la adopción de novedades no fue solo consecuencia automática del peligro militar sufrido por los reinos, sino producto de negociaciones que intentaron integrar esas novedades dentro del orden social y político del reino, que era normalmente visto como parte del orden natural y universal. En ese artículo se analiza el desarrollo de esas innovaciones y cómo se entendía a la luz de la razón natural tradicional, pese a la difusión de la moderna idea de razón de estado.
\end{abstract}

Palabras clave: Monarquía Hispánica, reino de Valencia, Felipe II, razón natural, defensa.

ABstract. In the 16th century the diffusion of military innovations altered the military administration of the Mediterranean kingdoms of the spanish monarchy, in particular the kingdom of Valencia. But the adoption of novelties was not only an automatic result of military danger, but an outcome of negotiations that attempted to integrate those novelties within the kingdom's social and political order, usually seen as a part of the natural and universal order. This article analyzes the development of these innovations and how they were understood in the light of traditional natural reason, despite the spread of the modern idea of reason of state.

Keywords: Spanish Monarchy, Kingdom of Valencia, Philip II, natural reason, defense.

Recibido: 21-10-2020-Aceptado: 2-05-2021-juan.fco.pardo@uv.es 
A LO LARGO DEL SIGLO XVI las estructuras defensivas de numerosos reinos y repúblicas europeas experimentaron un crecimiento notorio. Este proceso desembocó en una complicación de la administración de la defensa, que se dotó de nuevos instrumentos humanos, técnicos y financieros. En los reinos mediterráneos de la Monarquía Hispánica la fortificación moderna o la creación de cuerpos de custodia del litoral dan fe de aquellas innovaciones. Como es lógico, esas novedades no se introducían en el vacío, sino en ordenamientos institucionales, de modo que, en torno a su adopción, se generaron debates sobre la gravedad de las amenazas y sobre qué elementos defensivos cabía oponerles. Esos debates partían de dos premisas. Primero, el orden político, social y militar de cada territorio no era arbitrario y no podía alterarse a la ligera. Y, segundo, la comprensión, y, por tanto, la reforma de ese orden particular, en la medida en que, como se hacía tradicionalmente, fuese considerado reflejo del orden natural universal inspirado por Dios, debía hacerse mediante una razón igualmente natural, universal y de inspiración divina. Estas premisas habían guiado durante siglos tanto el pensamiento como la práctica de gobierno. Pero en aquella centuria se abrió paso la posibilidad de recurrir a una razón política que actuase con criterios propios, sin fundamentos universales y necesarios sino contingentes. Mi objetivo es estudiar el desarrollo de la política defensiva y qué tipo de razón se le aplicaba. Para ello se analizarán las medidas defensivas impulsadas en el reino de Valencia por los virreyes de Felipe II, en particular Bernardino de Cárdenas, duque de Maqueda, Íñigo López de Mendoza, marqués de Mondéjar, y Vespasiano Gonzaga, príncipe de Sabbioneta, sobre el trasfondo de los escritos de dos de los pensadores valencianos más relevantes del momento, Fadrique Furió Ceriol y Tomás Cerdán de Tallada.

\section{Razón, orden y defensa}

A principios de la edad moderna el mundo se concebía sujeto a un orden de creación divina que podía ser entendido por la razón natural o recta ratio. El Hacedor había revelado ese orden en las Escrituras y en su propia obra, y no era solo fundamento del mundo físico, sino también del buen gobierno (Jouanna, 2013, pp. 35-39). Este planteamiento no era exclusivo de teólogos, sino que estaba presente en toda la cultura y se manifestaba, al margen de la variedad de escuelas filosóficas, en ideas tan extendidas como la plenitud y continuidad de la creación o la correspondencia entre macrocosmos y microcosmos (Lovejoy, 1966; Berlin, 1981, pp. 67-68; Oakley, 1984, pp. 15-40; Gil Pujol, 2016, pp. 19-20, 36, 46). La política reposaba en esas concepciones y explicaciones de ese tipo se encontraban por doquier, incluso en los tratados sobre el príncipe y la república. Uno de los autores más leídos en la España del siglo XVI, Antonio de Guevara, se servía con profusión de estas ideas, a través de metáforas conocidas, para explicar que la política debía encajar con el orden del 
mundo instituido por Dios; y también la milicia, pues el gobierno militar debía ejercerse con parecidos valores (Guevara, 1994, pp. 281-291; Ídem, 1850, pp. 88a-89b). En la defensa con mayor motivo que en la guerra ofensiva, pues se esperaba que los reinos fuesen administrados con arreglo a sus leyes y costumbres, las cuales no eran sino adaptaciones a cada región de aquel orden natural y universal, que, asimismo, determinaba el lugar de cada cual en la sociedad y sus obligaciones con la comunidad (Hespanha, 2002, pp. 58-70, 100-101). Por eso el orden tradicional de la defensa se basaba en el servicio que cada uno debía prestar de acuerdo con su condición. No es extraño que en 1519 se rechazase en Valencia el empleo de soldados profesionales para la defensa de la costa con argumentos relacionados con el honor del reino: la defensa tocaba a la obligación de cada cual y del conjunto de la comunidad política (Pardo Molero, 2001, 83-92; Ídem, 2017, 785-790).

Ese orden no se creía inmutable. Con la mudanza de tiempos y gentes, el gobierno cambiaba e incorporaba nuevos elementos. Pero aquel teórico orden del mundo y de la sociedad seguía siendo la referencia que guiaba cualquier reforma, entendida como restitución de la situación adecuada mediante actos de justicia o de poder extraordinario (Hespanha, 2002, pp. 62-64; Jouanna, 2013, pp. 39-43; Gil Pujol, 2016, p. 49). Las innovaciones defensivas impulsadas por los Reyes Católicos y Carlos V no escapaban a esa norma, al deseo de reformar para restituir el orden, canalizado mediante debates y negociaciones encaminados a mantener los equilibrios políticos y sociales. Como resultado, a mediados del siglo XVI a los componentes tradicionales de la defensa se sumaban nuevas pautas de organización, armamento, fortificación, reclutamiento y financiación, plasmadas en cuerpos de infantería y caballería regular, escuadras de galeras, redes de torres de vigilancia, artillería moderna, castillos y murallas renovados, etc., que, a menudo, iban mucho más allá de lo que, a principios de la centuria, los diferentes actores habrían estado dispuestos a aceptar (Hernando Sánchez, 1994, pp. 384-436; Ídem, 2000; Pardo Molero, 2001; Jiménez Estrella, 2004; Escribano Páez, 2015). Aun así, persistía la creencia en un orden que, al igual que gobernaba la sociedad y el mundo, gobernaba la defensa, aunque la realidad se hubiese transformado. Una transformación que solía reflejarse en instrucciones y ordenanzas, instrumentos que no pretendían sino reducir la realidad a la razón.

Pero el concepto de razón como base de la política también estaba cambiando. La irrupción de la idea de razón de estado se vincula a la obra de Nicolás Maquiavelo, que habría establecido con claridad la liberación de la política con respecto a la religión y la moral, lo que expresaba la célebre máxima de que el fin justifica los medios. En realidad, la reflexión política del florentino no giró tanto sobre el fin y los medios $^{1}$, como sobre la posibilidad de afrontar con éxito los desafíos de la fortuna.

1 Catherine H. Zuckert (2017, pp. 83-84, 134) comenta fórmulas parecidas a la que se le atribuye en El Príncipe, 18, y los Discorsi, I, 9 (Machiavelli, 1989, pp. 90b y 584a). 
Su respuesta, como es sabido, era el recurso a una virtud renovada, de raíces clásicas, que preparase al ciudadano o al príncipe para tomar las decisiones que más beneficiaran a la república o principado, mediante una razón hecha de estudio y audacia, que no reposaba sobre la base religiosa y moral tradicional sino sobre un sistema de valores propio. No cabe duda, pues, de la influencia de Maquiavelo (y de autores coetáneos, como Francesco Guicciardini) en el deslizamiento de la tradicional ratio status, vinculada a la recta ratio, hacia terrenos apartados de la religión y la moral convencionales y, por tanto, del orden necesario que se desprendía de aquellas, para dejarla en el dominio de lo contingente (Berlin, 1981, pp. 67-71; Oakley, 2015, pp. 79-80; Senellart, 1995; Najemy, 2010; Viroli, 2009, pp. 161-235; Quaglioni, 2011, pp. 57-75; Howard, 2014, pp. 33-40).

Esta nueva razón fue explicada en términos negativos hacia 1549 por Giovanni della Casa, arzobispo de Benevento. Frente a la razón tradicional, «semplice et diritta et constante», propia de hombres, inspirada por la justicia y guiada por Dios, que debía servir tanto para el gobierno como para las diferencias entre particulares, se esgrimía otra, que se decía adecuada para «il governo de’Reami e de gli imperij», y que el prelado calificaba de «torta et falsa et dissoluta, et disposta a robare et a mal fare», a la que se llamaba «ragion di stato», pero que era más propia de las bestias que de los hombres (Albonico, 2015, p. 102). La denuncia del eclesiástico se dirigía al emperador Carlos V por su controvertida participación en el complot que acabó con la vida de Pier Luigi Farnese, y permitió reincorporar Piacenza al ducado de Milán (De Mattei, 1958; Ídem, 1979, pp. 10-23; Bertomeu Masiá, 2009). La crítica de Giovanni della Casa de la nueva y perversa razón de estado daba en el clavo, al discernirla de la razón natural y tradicional, vinculada a la Revelación y, por tanto, a la existencia de un orden cognoscible del mundo no totalmente sujeto a contigencia. Para el eclesiástico, esas dos razones servían de criterio para juzgar la política.

El triunfo de la razón de estado marca, según el análisis de Maurizio Viroli, la transición del arte de la política, basado en la moral tradicional, al arte del estado, desconectado de aquella y con sus propios valores (Viroli, 2009). No obstante, pese al impacto de la nueva razón de estado en la teoría y la práctica, la mayoría de escritores y de políticos siguieron durante largo tiempo refiriéndose a la idea tradicional de razón natural, común a la humanidad e inspirada por Dios, clave del orden del mundo y del gobierno; lo que no impedía, hasta entrada la segunda mitad del siglo xvI, leer y asimilar las obras de Maquiavelo (Puigdomènech Forcada, 1988; Howard, 2014, pp. 6-8). $\mathrm{Y}$ en esas coordenadas siguió entendiéndose la defensa. Evidentemente, nadie iba a argumentar abiertamente en nombre de una razón expresada en términos tan negativos como los utilizados por Della Casa, ni tampoco era excesivamente común antes de las últimas décadas del siglo XVI (De Mattei, 1979, pp. 24-30). Pero sí podrían esperarse, en los escritos políticos y de gobierno, usos de la razón que no estén vinculados a un 
orden universal y necesario. Los cambios en la organización defensiva pueden dar testimonio de cómo se aludía a la razón en un aspecto de vital importancia.

A lo largo del reinado de Carlos V las estructuras militares y defensivas del reino de Valencia sufrieron una tensión inusitada, primero en las guerras de 1521 a 1526 (revuelta de las Germanías y levantamientos musulmanes), y, enseguida, por la presión ejercida en el litoral por los corsarios norteafricanos y las escuadras turcas, vivida con creciente ansiedad (Pardo Molero, 2001). El resultado fue un ajuste constante de los mecanismos defensivos, que transformó el panorama militar del reino, el cual, sin embargo, siguió interpretado en términos compatibles con el ordenamiento político tradicional. Así lo reflejan numerosos memoriales e instrucciones elaborados por oficiales reales o por agentes de los estamentos, cuyo trasfondo era la certidumbre de que podía organizarse una defensa idónea del reino que articulase sus recursos, con auxilio de la Corona, sin alterar su orden sociopolítico, tanto en su naturaleza feudal, jerárquica y estamental, como en su vinculación con el orden universal, y, por tanto, sin apartarse de los dictados de la razón natural. Es en ese marco en el que, en la década de 1550, se acometió una de las mayores reformas de la defensa del litoral valenciano, bajo la presidencia de un nuevo virrey, Bernardino de Cárdenas, duque de Maqueda y marqués de Elche.

\section{La reforma de la defensa}

Maqueda había servido en diversas campañas con el emperador hasta que, en 1548, fue nombrado virrey de Navarra. Aquel reino había experimentado, desde la conquista de 1512, una transformación defensiva mucho mayor que el de Valencia, de modo que las innovaciones en soldados, artillería o fortificaciones, se habían convertido en parte del paisaje (Escribano Páez, 2015). Aun así, en cuanto llegó a Pamplona, don Bernardino no dejó de solicitar refuerzos: concretamente soldados de infantería y caballería y expertos en fortificaciones. Era lo que, de acuerdo con su experiencia y con la organización del reino, entendía necesario para tener en buen orden la defensa. Pero ya en 1549 anunció su disgusto porque «no se proveen las cosas tan a su propósito como querría». Como el gobierno de regencia en España, a cargo de los archiduques Maximiliano y María, admitía, aunque el virrey no hacía más que «desear que lo de aquel reyno esté con el buen recaudo ques menester», lo que se le concedía no llegaba más que a tenerlo «medianamente proveydo» (Rodríguez Raso, 1963, pp. 82, 88, 163, 231; Fernández Álvarez, 2003, III, pp. 128-129, 152 y 155-156). La queja del virrey y la respuesta gubernamental evocan el orden que debería tener la defensa, solo a medias alcanzado. Con todo, Maqueda permaneció en Navarra hasta fines de 1552, cuando fue designado para el virreinato de Valencia (García Bourrellier, 2018). 
Don Bernardino acudió a Valencia con instrucciones para encargarse de la guardia del reino (Fernández Álvarez, 2003, pp. 474, 537). En 1552 había asistido a las cortes de Monzón, en las que se adoptaron acuerdos trascendentales para la defensa: insistir en la fortificación de los lugares clave del litoral, levantar torres de vigía a lo largo de la costa, organizar una guarda terrestre, aprobar un impuesto para sustentarla, e instituir una junta de 18 representantes de los tres estamentos, presididos por el virrey, para gobernarla. Para ponerlos en práctica, Maqueda no tardó en emprender una visita de la costa, al cabo de la cual admitía «la gran necessidad que tiene de guarda», y la urgencia de proceder con «algún más cuidado que hasta aquí». Pero en Valencia, a diferencia de Navarra, sus ideas sobre el orden del territorio estaban influidas por su condición de señor del reino y por el hecho de que su marquesado de Elche se extendía hasta la costa. En buena lógica, debía de sentirse decepcionado por no sacarle todo el rendimiento, desperdiciando sus condiciones naturales. Quizá por eso, una vez acabada su inspección de la costa, escribiendo desde la capital de su señorío en febrero de 1553, acerca de los perjuicios que acarreaba la mala defensa, subrayaba que «demás del daño que recibe el reyno en no poderse aprovechar de sus términos, es gran desautoridad que lo dexe de hazer por no tener qüenta con ellos ni cuidado de guardarlos $\rangle^{2}$. Una reflexión que aunaba rendimiento económico, defensa y honor del reino, cuya restauración requería actuar sin dilación, tal y como habían decidido las cortes. En los meses siguientes, la política militar del nuevo virrey consistiría en organizar la defensa del reino de acuerdo con un orden renovado. Para ello se centraría en movilizar los recursos locales y en solicitar al gobierno de regencia, presidido ahora por el príncipe Felipe, que los completase en varios sentidos: fortificación, artillería y gente de guerra.

El virrey anotó esas pautas en un memorial que envió a la corte a mediados de abril. Como primera providencia, insistía en suplicar al príncipe «por la venida de miçer Juan Baptitsta Calvi, yngeniero», siempre que se lo permitiese el trabajo que estaba haciendo en Rosas y Barcelona. Según Maqueda, su estancia en Valencia sería breve: «en un mes podrá yr y bolver, y con su pareçer se començará la fortificaçión de las plaças que se ovieren de reparar, de que ay gran neçesidad». Pese a esa necesidad, don Bernardino prefería no empezar con las obras en torres y plazas fuertes antes de la llegada de Calvi, «por no averlo de hazer dos vezes». En segundo lugar, la artillería: en su visita al reino, pudo ver algunas piezas aquí y allá, pero «tan mal tractadas y tan sin orden y desproveídas de muniçiones que es como tener en pasta el metal». También en este capítulo esperaba que se le enviasen expertos (artilleros y fundidor) para poner «en orden» la artillería del reino. En cuanto a la gente de guerra, Maqueda

2 Archivo General de Simancas (en adelante AGS), Estado, Aragón, 314, f. 64, Maqueda al príncipe, Elche, 18 de febrero de 1553. 
lo abordó en dos partes. Primero, la guardia ordinaria, que calculaba que debían ser «hasta dozientos honbres de pie y sesenta o setenta de cavallo»; para juntarla su idea era «meter alguna gente del reyno de Granada o del de Murcia o Andaluzía para la guarda deste, porque ha pareçido que se haría mejor con estrangeros»; y, segundo, para mejorar las huestes y milicias locales, recordó al príncipe la «gran necessidad de cavallos» que había en el reino ${ }^{3}$. Las tres peticiones del virrey obedecen, sin duda, al designio de modernizar la defensa del reino. Pero cabe entenderlas de acuerdo con la intención de reformarla sin alterar el equilibrio social y político, el «orden» del reino. Así, con las impresiones de su visita de la costa aún frescas confiaba en que, levantando las torres de vigía previstas y fortificando los lugares de la costa «se porná todo en razón» ${ }^{4}$. Por eso pensaba en soluciones duraderas: fortificaciones diseñadas por un ingeniero, artillería fundida y organizada por expertos, soldados sin arraigo para la guardia permanente, y una caballería acorde con la nobleza del reino; pero todo ello encajado en el orden local.

Maqueda atribuía gran importancia a las obras de fortificación y a las novedades arquitectónicas de la época, un interés que podía ser fruto de su estancia en Navarra, pero que compartía con su generación (Hernando Sánchez, 2000). Pero, por mucho que comprendiera la necesidad de contar con el ingeniero para el diseño de las torres del litoral, no esperó a tener noticias de Calvi para enviar a las localidades costeras comisarios bien provistos de instrucciones con la misión de negociar con las autoridades «totes les coses concernents y necessàries al bé, comoditat y promptitut de la fàbrica e constructió de les dites torres y atalayes», y para que tuviesen a punto lo necesario para su edificación ${ }^{5}$.

Asimismo, para poner en orden la artillería que en tan mal estado encontró, solicitó al príncipe que hiciese venir de Pamplona o de Burgos varios artilleros y un fundidor. Don Felipe accedió a enviar el personal solicitado, siempre y cuando se hiciera «sin hazer falta acá» ${ }^{6}$. El duque, sin embargo, que tenía preferencias por un par de artilleros, aseguraba que podía prescindirse de ellos en sus actuales destinos: por ejemplo, de uno de ellos, llamado Aguilar, destinado en Navarra, decía que ya no tenía «qué hazer, porque lo de allí quedó ordenado, de manera que el mayor cuidado que ha menester es conservarlo en la orden que está». Eso era lo que el artillero debía hacer en Valencia: poner las cosas en orden de modo que, una vez «esté ordenado

3 AGS, Estado, Aragón, 314, f. 66: «Memorial de las cosas que se suplican a Su Alteza para la buena guarda de la costa del reyno de Valencia»; enviado con carta al príncipe, de Valencia, 17 de abril de 1553 (f. 65).

4 AGS, Estado, Aragón, 314, f. 64, Maqueda al príncipe, Elche, 18 de febrero de 1553.

5 Archivo del Reino de Valencia (en adelante ARV), Real Cancillería, Curiae Locumtenentiae, 1323, ff. 192v-193v; da la referencia del documento Salvador Lizondo (1986, pp. 240-241).

6 AGS, Estado, Aragón, 313, f. 344, el príncipe a Maqueda, Madrid, 6 de febrero de 1553, y 314, f. 66, Memorial, ya citado. 
lo de acá, se podrá volver» ${ }^{7}$. Lo mismo ocurriría con el fundidor: se trataba de dejar organizada una fundición en Valencia para que, en adelante, el reino resolviese sus problemas artilleros sin ayuda de fuera. Según sus palabras,

de hazerse esta fundiçión aquí, ay algunos ofiçiales que quedarían pláticos para otra, y es bien que en este reyno aya de quien se pueda fiar, porque, aviendo artillería, sienpre se ronpe, y salen algunas pieças mal acondiçionadas, por donde conviene que aya, de ordinario, fundidor ${ }^{8}$.

Como con la fortificación, se trataba de reformar el orden defensivo para dejarlo en mejores condiciones.

Pero ninguna provisión serviría de nada sin gente que sirviese los cañones, guareciese las torres y fortalezas o vigilase la costa. Desde primeros de año, Maqueda había trasladado al príncipe Felipe la necesidad de contar con una tropa regular, y había señalado su preferencia por que no estuviese formada por naturales del reino. En abril, la llegada de unas cuantas fustas corsarias a las inmediaciones del Peñón de Ifach le había reafirmado en esa convicción, pues los vigías locales habían abandonado sus puestos. Según señalaba el virrey en carta a don Felipe, si esa guardia «la tuvieran estrangeros, no la desanpararan así». La razón no estaba en que la gente del reino «no sea buena para otra parte», sino en que teniendo cerca «sus mugeres e hijos y hazienda, de que veen alguna neçesidad, antes acuden a sus casas que a la guarda que les está encargada ${ }^{9}$. Se trataba de la aplicación de un principio general, característico de la administración militar, que no alteraba radicalmente el orden general del reino, pues se limitaba a la infantería y caballería que había de constituir la guardia ordinaria y permanente del reino, en contingentes muy limitados, no mucho mayores de los constituidos intermitentemente en la época del virrey Fernando de Aragón, duque de Calabria (Pardo Molero, 2001, pp. 205-407). En caso de alarma, y como se hacía también en ese tiempo, don Bernardino era consciente de la necesidad de movilizar las huestes locales y señoriales, y por eso se afanaba en enviar cartas de apercibimiento en los momentos de alerta (Salvador Lizondo, 1986, I, pp. 239-240).

Para que las fuerzas locales actuasen adecuadamente, pidió al príncipe autorización para conceder licencias para importar caballos, de los que había una notoria carencia en el reino. Entendía que, con las licencias en la mano, podría fomentar la emulación entre la gente de condición, pues «con encavalgarse algunos, otros, por no hallarse a pie, procurarían hazer lo mesmo». 
Pero el proceso sería largo, por lo que el duque solicitó con insistencia que, por el momento, se le enviase una compañía de caballos ligeros de las ya formadas en Castilla, cuya paga correría a cargo de los fondos aprobados en cortes. Haciéndose así, explicaba, además de que la Corona se ahorraría el sueldo de esa compañía mientras estuviera en Valencia (tiempo en que la paga iría a cargo del reino), se podría reclutar «de espaçio y mejor la gente que acá oviese de estar de asiento», es decir, la caballería regular. El príncipe, acaso más atento que su virrey a los equilibrios territoriales, se negó al envío de la compañía pedida con un escueto «no conviene» ${ }^{10}$. Pero los planes de reforma de Maqueda eran ambiciosos. Confiaba en que sus medidas mejorarían el orden general del reino no sólo en lo relativo a la defensa, pues, como apuntó a propósito de su demanda de gente y caballos, «aunque el fin prinçipal sea para guarda de la costa, no dexará de ser en gran autoridad de la buena administración de la justicia» ${ }^{11}$. Por eso siguió durante meses con su letanía, cada vez más apremiante, hasta que el 12 de agosto escribió, desabrido, que,

este reyno está tan desaperçebido como otras vezes tengo scrito, y pudiéndose proveer en algunas cosas sin costa de Su Magestad ni de Vuestra Alteza, pareçe descuido no permitirlo. Suplico a Vuestra Alteza mire en ello, y que si en Cathalunia quisieren hazer çient cavallos ligeros a su costa, sí se le admittiría, y aun con agimiento de gracias, y aquí se ruega por ello muchos días ha, y no somos admittidos, pero la neçessidad me haze ser ymportuno a Vuestra Alteza ${ }^{12}$.

Dadas sus intenciones reformadoras, su insistencia estaba justificada, pues, como explicó pocos días después, en cuanto dispusiese de la gente y de los caballos necesarios, «se començaría a poner en alguna orden el reyno» ${ }^{13}$.

Ese orden que el virrey quería no obedecía solo a sus planes, sino que se derivaba de los acuerdos de las cortes, uno de cuyos resultados más tangibles fueron las ordenanzas de 1554 para la guardia de la costa. El documento supuso una novedad en Valencia, al regular y unificar los procedimientos y la administración de la guardia: desde el reclutamiento del personal hasta sus obligaciones, pasando por las labores de inspección de toda la estructura, que dependería de la junta de los 18 representantes estamentales, radicada en la capital del reino. La instrucción, que, según dice su preámbulo, tenía por objeto que «la gente de pie y de caballo neçessaria» estuviese «en más recaudo y seguridad y mejor regida», se elaboró «con paresçer y consejo de personas expertas, ansí de las cosas deste reyno y costa dél, como de lo que se haze en otros»: de hecho, gran parte de su articulado seguía prácticas defensivas vigentes

10 AGS, Estado, Aragón, 314, f. 66.

11 AGS, Estado, Aragón, 314, f. 52, Maqueda al príncipe, Valencia, 2 de junio de 1553.

12 AGS, Estado, Aragón, 314, f. 51; véase también f. 71, de 6 de mayo,

13 AGS, Estado, Aragón, 314, 50, Valencia, 21 de agosto de 1553, Maqueda al príncipe. 
en el reino de Granada desde principios de siglo, que años atrás habían despertado el interés de las autoridades valencianas ${ }^{14}$.

El nuevo cuerpo de guardia de la costa, ordinario, regular y perpetuo, contrastaba con las atalayas intermitentes que colocaban los municipios costeros en momentos de alerta, y con las tradicionales huestes municipales y señoriales. Pero no las reemplazó totalmente (especialmente a las últimas), sino que unos y otros debían funcionar como un todo orgánico. En el fondo, la reforma defensiva de Maqueda remitía a un orden en el que cada pieza o miembro, en su lugar y cumpliendo con su finalidad, serviría para proteger al conjunto del reino. Una coordinación visible en las primeras órdenes de apercibimiento dadas por don Bernardino, que recordaban a las autoridades locales su deber de avisar en las alertas «a los circunvesinos de que soléys ser socorridos, para que ellos estén apercebidos», a fin de que, «en caso de necesidad, se puedan mejor defender de los enemigos y offenderlos y socorrer y ayudar los unos pueblos a los otros» ${ }^{15}$. El cumplimiento de esas obligaciones mutuas debía basarse en el honor de las partes, fundamento de las huestes locales.

De ello dan fe las provisiones dadas en 1555, ante noticias sobre la inminente venida de la Armada turca y sus intenciones de juntarse «con las galeras de Francia y de Argel y otros muchos cossarios infieles». Dado que «las tierras deste reyno sean las más marítimas y las otras tan cercanas de la mar», se ordenó que todos los municipios estuvieran «apercebidos por lo que podría suceder si la dicha Armada viniesse a estas partes». En las instrucciones particulares que se enviaron a Orihuela y Alicante, el virrey mandó que, haciéndose alarde de la población útil, se comprobase que las huestes de ambas ciudades y de sus huertas contaban con armas suficientes, y que quien careciese de ellas las comprara. No era ocioso tomar estas precauciones con esas ciudades, pues sus milicias tenían un elevado componente de caballería honrada: aquellos vecinos que se reputaban capaces de mantener un caballo y el equipo militar correspondiente eran los que optaban a los cargos del gobierno local (Bernabé Gil, 1990). De ahí que el virrey ordenase al gobernador que, en el alarde de la hueste de Orihuela tuviese «consideración a dar a cada uno el lugar que le pertenesciere según la qualidad de su persona [...], guardando a cada uno su autoridad». De esta manera, cundiría la emulación: «todos holgarán, y los que no pudieren servir a pie, procurarán de tener cavallos, y los que los tuvieren de conservarlos por poder mejor servir». Como recalcaba don Bernardino, no se trataba «de mandar a nadi cosa que no deva ni pueda hazer», sino todo lo contrario: su intención era «que

14 Pardo Molero, 2001, p. 430, y 2006; las ordenanzas, tomadas de la Real Cancillería valenciana, fueron incluidas por Salvador Lizondo en el apéndice documental de su tesis doctoral, véase Salvador Lizondo (1984, II, pp. 427-436); por mi parte, cito por el documento conservado en Archivo de la Nobleza, Osuna, leg. 2858-1.

15 ARV, Real Cancillería, Curiae Locumtenentiae, 1323, f. 183r-v, el virrey al justicia y jurados de Alicante, Valencia, 23 de marzo de 1553. 
todos entiendan que la honra verdadera está en que cada uno sirva a su república y a su rey como mejor pudiere» ${ }^{16}$. Pese a las novedades introducidas en la custodia del litoral, el virrey asumía la equivalencia entre honor y defensa, de modo que el orden social estamental, que no podía ser totalmente contingente, seguía siendo clave de la conservación del reino.

\section{Razón política y defensa}

Esta concepción del reino no difería demasiado de la que subyace a la mayoría de la literatura política de la época. La fe en la misma razón que inspiraba confianza al duque de Maqueda para poner en orden la defensa se reflejaba en los escritores, que la expresaban mediante las tradicionales analogías corporativas y la equivalencia entre macrocosmos y microcosmos. Así puede entenderse, incluso en algunos de los autores más audaces de aquellos años, el recurso a la razón, sin necesidad de atribuirle plena autonomía o secularización. Es el caso de Sebastián Fox Morcillo, uno de los primeros escritores españoles en aprovechar la obra de Maquiavelo, en el periodo en que el florentino aún no era tenido por poco menos que el Anticristo. Formado en Lovaina, se ha destacado de sus escritos su racionalismo casi moderno (Maravall Casesnoves, 1972, I, p. 78; Ídem, 1986, pp. 470 y 517; Truman, 1999, pp. 39-68); sin embargo, en su tratado de 1556 sobre la institución real pone en boca de uno de sus personajes la tópica comparación entre el reino y el cuerpo humano, y la armonía que, al modo musical, debe reinar entre los miembros de uno y otro (Fox Morcillo, 1556, lib. I, B5, ff. 4-5): como ha señalado Ronald W. Truman, la aproximación terrenal que hace Morcillo a los problemas políticos, incluso su utilización de ideas maquiavelianas, no le impiden atribuir a la sociedad y a la política una base moral tradicional (Truman, 1999, pp. 67-68).

Nos interesa más su compañero de estudios valenciano, Fadrique Furió Ceriol, que debía estar al corriente de los problemas políticos y militares de su reino natal. Considerado uno de los pensadores españoles más originales del siglo XVI, se suele subrayar su talante irénico y su compromiso con la traducción de las Escrituras a la lengua vulgar, pero también el carácter secularizado de la razón en sus escritos políticos y su asimilación del lenguaje y los conceptos de Maquiavelo (Bataillon, 1966, pp. 552-554; García Pinilla, 2003; Méchoulan, 1978; Truman, 1999, pp. 89-114; Howard, 2011; Ídem, 2014, pp. 52-63; Álvarez García, 2016). En su celebrado Concejo y consejeros del príncipe, habría dado fe de esa vocación secular al comentar la separación entre las personas pública y privada del monarca, al valorar las competencias técnicas de los ministros, y no sus virtudes religiosas, o al no despreciar las capacidades de las 
gentes de otros credos. Pero no por ello puede decirse que el pensamiento de Furió se adscribiese, no ya a algunas ideas de Maquiavelo (lo que está fuera de duda), sino al concepto de razón de estado en tanto que razón política específica al margen de la clásica razón natural. Al contrario, parece que, como Morcillo, Furió no se apartó de la creencia en un orden universal: al equiparar el consejo a los órganos y sentidos del cuerpo no hacía más que aplicar la vieja equivalencia entre microcosmos y macrocosmos; más aún, al afirmar que rey y consejo son «tenientes de Dios acá en la tierra», si no daba por bueno el origen divino del poder real (cosa que deja clara al sostener que la persona pública del príncipe es «merced de fortuna i favor del cielo»), como mínimo establecía una correspondencia entre el orden terrestre y el divino, del que aquel es reflejo (Furió Ceriol, 1996, p. 91). Incluso la mencionada dualidad de la persona del príncipe, de la que, por cierto, se había servido Della Casa, puede emparentarse con el concepto teológico-político de los dos cuerpos del rey, que Furió debía de conocer: aunque su exposición no esté tan cargada de misterio como en Francia e Inglaterra, no por ello dejaba de ser trascendente (De Mattei, 1958, pp. 215-216; Ídem, 1979, p. 19; Kantorowicz, 1957, pp. 366-368; Lisón Tolosana, 1991, pp. 75-92). Teniendo esto en cuenta, puede entenderse su valoración de las explicaciones que solían darse de las derrotas militares, en la que, con ironía, da la razón a quienes consideran que «nuestros pecados lo causan», pues, a su modo de ver, «los ierros i faltas del príncipe i de sus ruines consejeros, son pecados que nos acarrean la perdición nuestra i suya» (Furió Ceriol, 1996, p. 94). Más que a una secularización de la noción de pecado, señalada por Henry Méchoulan (Méchoulan, 1996, pp. 49-50), cabe apuntar en sentido opuesto, no necesariamente a la sacralización del gobierno, pero sí a su consideración trascendente, lo que convierte la falta de diligencia, de prudencia, o de fortaleza en pecados, no por morales menos graves que los puramente religiosos. Si, como se desprende de las anteriores analogías, existe una correlación entre el ámbito celestial y el humano, los actos de gobierno han de estar adecuadamente guiados por la razón natural, para que se correspondan con el orden al que la república debe tender.

La atención puesta por el virrey Maqueda en sus provisiones defensivas, propia de un experimentado oficial de la monarquía, coincidía con el espíritu de los consejos de Furió Ceriol: lejos de fiarlo todo a la Providencia, confiaba en el esfuerzo humano y en el correcto funcionamiento de los engranajes políticos, sociales y militares. Apartarse de lo que la razón prescribía significaba alejarse del orden correcto, una actitud negligente, poco virtuosa y menos honorable, casi un pecado. Pero, como hemos visto, eso no quiere decir que no fuese posible, mediante la razón, introducir cambios y novedades que reformasen aquel orden, para hacerlo más acorde a las necesidades, sin violentar los equilibrios sociopolíticos. Durante todo su virreinato, a cada nueva alerta don Bernardino dirigía la estructura defensiva inten- 
tando que funcionasen conjuntamente todos sus componentes, antiguos y modernos: apercibía los lugares cercanos al litoral, nombraba capitanes, supervisaba la fundición de artillería, así como el estado de plazas fuertes y guarniciones, la guardia de costa y las torres de vigía (Salvador Lizondo, 1986, I, pp. 250-273). Pese a todo ese trabajo, la costa no se inmunizó contra los ataques, pero las mejoras fueron visibles. La administración de la defensa se hizo más compleja, con más cabos que atender; es más, al reorganizarse en torno a instrumentos comunes para el reino, mantenía un carácter racional no ya por reducir sus componentes a pautas precisas, previsibles y lógicas, o por centralizarse o modernizarse, como también era pauta en otros reinos mediterráneos de la monarquía (Favarò, 2009), sino en un sentido que encajaba con la razón y el orden tradicionales.

Y ese orden tenía sus necesidades de revisión. De ahí las visitas del reino encargadas a comienzos de la década de 1560 al ingeniero Juan Bautista Antonelli. Su inspección y los informes que redactó se han considerado muestra de la modernización militar y del avance del control estatal (centralizado y burocrático) del territorio (Boira Mahiques, 1992). Con todo, las propuestas de Antonelli responden a la tradicional perspectiva de un orden del reino susceptible de ser conocido y mejorado por la razón. Las metáforas corporativas y organicistas con que describe el territorio implican menos una tentativa de control total que el deseo de aportar las mejoras necesarias a la naturaleza para hacer segura la frontera (Cámara Muñoz, 1989, pp. 90-91 $)^{17}$. Pero el proyecto que presentó para fortificar el litoral valenciano superaba con creces las posibilidades financieras del reino: en las cortes de 1564 se rechazaron las obras propuestas en villas y ciudades por encontrar que «no valen tant les mateixes ciutats e viles quant pujarien les dites obres». Los tres brazos del reino no sólo no encontraban conforme a razón tantos gastos y obras, sino que los veían «molt perjudicials axí al benefici públich de dites ciutats e viles com encara als particulars poblats en aquelles» ${ }^{18}$. En otras palabras, el plan del ingeniero no encajaba en el orden del reino.

Aunque el ambicioso proyecto de Antonelli no se acometiera, las reformas introducidas desde el decenio anterior parecían dar buenos resultados. Lo creía Felipe II en enero de 1566, cuando encareció al virrey de Cataluña, Diego Hurtado de Mendoza, el «gran provecho que han hecho las torres que están en la marina del nuestro Reyno de Valencia», provecho que, según decía, era «tanto, que después que se edi-

17 AGS, Guerra y Marina, Guerra Antigua, 70, ff. 164-166, cartas de Felipe II al maestre racional, al virrey, a los diputados y a los estamentos del reino, y 72, f. 182, «Relación de la costa del reyno de Valençia».

18 La respuesta de los estamentos al plan de Antonelli es el cap. CXV de los tres brazos de las Cortes de 1564: Salvador Esteban, 1973, pp. 41b-42a. Con «valer», los estamentos probablemente se referían no a su valor total sino a la renta que reportaban los municipios: Diccionari Alcover-Moll, Català Valencià Balear, s.v. «valer», sexta acepción. 
ficaron ningún hombre se ha cativado en dicho Reyno». Tan favorable visión de la defensa del reino de Valencia, que no debía de ser ajena a la tranquilidad de aquellos años en la costa (Piles Almela, 1981-1982, pp. 255-257), llevaba al rey a aconsejar a Mendoza «que platiquéis si será bien que en la costa desse Principado y condados» se adoptase un sistema parecido ${ }^{19}$. Para ello le envió una instrucción de la que se infiere lo que él y sus consejeros entendían del funcionamiento de la red de torres. Para empezar, aunque se refería a todo el principado, don Felipe llamaba la atención sobre un área concreta, la comprendida entre Sol de Riu, en la desembocadura del río Cenia, límite con el reino de Valencia, y el islote del Torn, en el término de Vandellós, «que es todo lo principal de las marinas desse Principado donde se recogen fustas». La propuesta era construir,

en las calas y puertos, algunas torres donde pudiesse aver, en cada una, dos o tres hombres con tres o quatro pieças pequeñas de artillería, que sirviessen assí para avisar la tierra quando huviesse enemigos, como para escusar que no tomassen agua ni se pudiessen guarescer con tormenta las fustas y galeotas que ordinariamente vienen a buscar aquel abrigo quando andan por essa costa.

Se trataba de reforzar los lugares más amenazados con un dispositivo que cumpliera la doble misión de ahuyentar a los enemigos y prevenir a los naturales: es decir, completar la defensa tradicional con instrumentos modernos (torres y artillería), manejados por una pequeña tropa regular. Asimismo, don Felipe apuntaba al puerto de Los Alfaques, que, por su gran tamaño y por contar con suministro de agua potable, veía como el «receptáculo principal de todos los navíos de turcos que vienen a hazer daño», y como refugio seguro para «qualquier armada de treinta, quarenta o cinquenta navíos». Por eso aconsejaba debatir,

con las personas pláticas dessa tierra que tengan noticia dello, si sería bien hazer dos torres o tres para sola la guardia del dicho puerto, que fuessen más capaces de gente que las otras, y pudiesse aver en cada una cinco o seis hombres, con quatro o cinco pieças de artillería, que bastarían a assegurar todos los buenos surgideros, porque se alançarían las pelotas de una parte y de otra.

El debate con las personas experimentadas (la plática) se convertía en clave del asunto, para conducir, conforme a razón y experiencia, la reforma del orden defensivo. Un debate que el monarca extendía a la financiación del proyecto, o sea, a «qué ayuda se hará en esse Principado para ponerlo por obra [...], y lo que podrían costar

19 El rey al virrey de Cataluña, Madrid, 31 de enero de 1566, Archivo de la Corona de Aragón (en adelante ACA), Cancillería, Curiae Sigilli Secreti, 4350, ff. 206v-207v (f. 206v); cita el pasaje brevemente Reglá Campistol (2000, p. 175). 
los edificios y la guarda ordinaria que en ellos avía de residir». Don Felipe concluía que aquello sería «el mayor beneficio que a essa tierra se pueda hazer» ${ }^{20}$.

\section{La ampliación de las reformas}

Por mucho entusiasmo que las torres despertaran en el rey, no iba a pasar demasiado tiempo sin que se planteasen reformas. Pero sería a raíz de delicadas coyunturas políticas y militares, relacionadas con el recelo hacia la minoría morisca. Primero, a causa de la guerra de las Alpujarras (1568-1571), que puso en alerta todo el Mediterráneo español, especialmente el reino de Valencia, por su elevado volumen de población morisca. Poco después, en 1574, la caída de Túnez y La Goleta en manos turcas reactivó las alarmas. Y en 1577 una nueva amenaza otomana reavivó los rumores de ataques y conspiraciones entre moriscos y turcos En esas ocasiones, la defensa del reino fue objeto de la atención de las autoridades, suscitando, en la corte y en Valencia, reflexiones encaminadas a adaptar la organización defensiva a la situación de alarma, pero teniendo en cuenta la idiosincrasia del reino.

Desde el comienzo de la rebelión morisca de Granada, los temores a episodios similares en Valencia no habían faltado (Salvador Esteban, 1987; Catalá Sanz-Urzainqui Sánchez, 2009). A fines de 1570, las noticias de una ofensiva de la Armada otomana, cuando aún no había concluido la guerra, exacerbaron la ansiedad y propiciaron planes para la defensa del reino, en relación con la política que había que adoptar hacia los moriscos. Así, en los Consejos de Estado y Guerra, al tiempo que se planeaba la deportación de los moriscos granadinos, se planteó la oportunidad de hacer lo propio con los valencianos, para evitar su contacto con los turcos. Consultado por Felipe II, el vicecanciller de Aragón, Bernardo de Bolea, analizó la situación. En su informe examinó la cuestión en términos de «coyuntura», lo que, en el lenguaje político de la época, significaba adaptar el saber humano a cada «ocasión», término equivalente a la fortuna maquiaveliana, sin su carga mitológica (Maravall, 1975, pp. 56-57 ${ }^{21}$ : o sea, aplicar la razón a una situación dada. Podía tratarse de la razón natural o de la de estado, pero lo propuesto por el vicecanciller apunta más a la primera, lo que no implica que no estuviese familiarizado con la segunda. Considerando que la deportación de toda la población morisca valenciana resultaría contraproducente, pues podría acarrear los males que pretendía evitar, Bolea proponía un desplazamiento temporal y limitado de los que vivían cerca de la costa, enfatizando

20 ACA, Cancillería, Curie Sigilli Secreti, 4350, ff. 206v-207v. Los sentidos de «plática» como conversación y razonamiento, y, como adjetivo, diestro y experimentado, los recoge Covarrubias, en su Tesoro (consultable en rae.es).

21 «Coyuntura» $\mathrm{y}$ «ocasión» son términos repetidos en el memorial de Bolea (publicado por Benítez Sánchez-Blanco, 1998, pp. 95 y 105). 
la necesidad de reforzar las defensas del reino con las medidas habituales: apercibimiento, revista de efectivos, rearme, nombramiento de capitanes, y, sobre todo, visita de la costa por el virrey, conde de Benavente, a quien se enviaron instrucciones específicas (Benítez Sánchez-Blanco, 2001, pp. 276-281; Belchí Navarro, 2006, pp. 234-235). La marcha de la guerra en Granada y las noticias tranquilizadoras de la Armada otomana relajaron la alarma defensiva. Es más, para calmar los ánimos de los moriscos del reino, temerosos de que se procediera con ellos como con los granadinos, y agobiados por la acción del Santo Oficio, se emprendieron negociaciones con las aljamas y sus señores, que culminaron en 1571 en un acuerdo que desactivó buena parte de la capacidad de resistencia de la minoría (Benítez Sánchez-Blanco, 2001, 221-264). La amenaza había pasado, pero se sentaron las bases para proceder en los años siguientes.

En 1574 de nuevo saltaron las alarmas. Como cuatro años antes, ante preocupantes noticias de la Armada turca, hubo reacciones a múltiples bandas. Ya en agosto el virrey, Íñigo López de Mendoza, marqués de Mondéjar, disgustó al estamento militar al exigirle que nombrase electos para discutir con él la política defensiva. Los nobles lo interpretaron como un menosprecio a sus libertades, pues en semejantes ocasiones actuaban libremente y según sus procedimientos (Lorite Martínez, 2017, pp. 127-128). Siendo la defensa parte del orden no contingente y, por tanto, del honor del reino, las resoluciones debían ser fruto de una deliberación conjunta que siguiera los cauces adecuados, en consonancia con el marco estamental. Pero cuando se conoció la caída de La Goleta, la presión para reforzar la defensa se incrementó.

Instruido por Felipe II, a mediados de noviembre el virrey convocó a los estamentos para proponerles participar, con los otros reinos de la Corona de Aragón, en la formación de una escuadra de galeras. Los estamentos comenzaron a debatir sobre la forma de reunir el dinero (Belchí Navarro, 2006, p. 236). Pero no era la primera vez que se presentaba un expediente similar, sin que acabase llevándose a la práctica, dada la poca confianza en el uso que acabase dando el rey a las galeras (Pardo Molero, 2001, pp. 271-273, 426-429). En las mismas fechas en que se reunía con los estamentos, Mondéjar asentó, en una larga memoria, aquello que consideraba necesario «para la guarda y deffensa del Reyno de Valencia, y speçialmente de los lugares martítimos», en aquel momento de alerta. El documento reviste un interés especial porque, poco más de un año después, lo utilizaría su sucesor, Vespasiano Gonzaga, para anotar lo que estaba hecho y justificar lo que quedaba por hacer ${ }^{22}$. Es,

22 Fechado en el Real de Valencia, a 18 de noviembre de 1574, es un documento conocido: puede encontrarse en la web (publicado por el Aula Militar Bermúdez de Castro: https://www.slideshare. net/aulamilitar/03-1574-relacin-del-marqus-de-mondejar, consultado a 30 de mayo de 2020). He manejado el de AGS, Guerra y Marina, Guerra Antigua, leg. 81, f. 38: «Lo que al Marqués de Mondéjar paresçe nesçessario para la defensa del Reyno de Valencia, y lo que sobre algunas cosas ha proveydo el Príncipe Vespasiano Gonzaga». 
pues, un diálogo entre dos virreyes y dos momentos defensivos diferentes, sobre la importancia y factibilidad de las medidas de defensa.

Tal y como la redactó, la relación de Mondéjar se estructuraba en torno a las obligaciones, en diversos niveles, de la sociedad valenciana hacia la defensa. Así, empezaba consigo mismo, recordando su obligación de visitar la costa del reino. A continuación venían los alcaides y sus castillos, núcleo del sistema militar tradicional del reino: se daban las consignas habituales para que residieran en sus fortalezas, o que «los que tubieren justo impedimento, pongan thenientes en ellas a contento del virrey»; que los castillos estuviesen reparados y provistos de gente, armas y municiones; y, finalmente que hubiese «gran cuidado de hazer las guardas y velar de día y de noche». Seguidamente prestaba atención al aparato de vigilancia litoral levantado en época de Maqueda. No solo debía completarse, reparándose las torres en mal estado o haciendo nuevas donde fuera necesario, sino que debía hacerse una revisión de todo el sistema de custodia, es decir, «reformar la guardia de la dicha costa», a fin de lograr un funcionamiento óptimo, haciendo que visitadores, requeridores, guardas y atajadores «guarden lo contenido en las instrucciones», y castigando a quienes no lo hicieran; pero también recomendaba actualizar las ordenanzas, «añadiendo, o quitando, o alterando de las dichas instrucciones lo que paresçiere neçessario para el buen recaudo de la dicha costa, conforme a la ocurrençia del tiempo». De esta forma, se preveía hacer frente a las contingencias con flexibilidad, pero dentro del orden general.

A continuación, se ocupaba de los municipios y sus huestes. El virrey recomendaba «tomar reseña general de toda la gente de pie y de cavallo de la ciudad de Valençia y de las o[tras] ciudades y villas deste Reyno»; y que, en lo sucesivo, se hiciesen alardes, por turnos, en domingos y festivos. Como veinte años antes el duque de Maqueda, Mondéjar tenía especial interés en la gente de caballo: debía ordenarse «que los cavalleros y otras personas que no tubieren cavallos y tubieren possibilidad de comprallos, los compren dentro de un breve término». A tal fin, pedía licencias para introducir en el reino monturas de Castilla, con garantías de que no fuesen objeto de ulterior tráfico. De hecho, debía levantarse un registro de todos los caballos, anotando «las hedades [...] y las colores y señales dellos». Toda la gente útil, de pie o de caballo, debía estar distribuida en compañías, y éstas en escuadras, con sus oficiales. Y los hombres de pie debían armarse «conforme a la possibilidad que cada uno tubiere», es decir, «que el que pudiere tener arcabuz le tenga, y el que no pudiere tener arcabuz tenga vallesta, y el que no pudiere vallesta, tenga pica». Asimismo, debía señalarse «en qué parte o partes ha de juntarse la gente» en caso de alarma, con indicación de «los lugares de marina donde cada compañía o squadra ha de acudir a la defensa, para escusar confussiones al tiempo de la neçessidad». Esta forma de colaboración no acababa en la frontera, pues había que dar orden para que «la gente 
del marquesado de Villena y de otros lugares de Castilla que están a la raya deste Reyno», estuviese lista para acudir al socorro, en caso de que fuese requerida por el virrey. Finalmente, en aquellos municipios que no pudiesen ponerse «en deffensa», aconsejaba que «se retire la gente dellos a tierra adentro, o a lo menos mugeres y niños y gente inútil, porque los demás puedan hazer con más façilidad y menos peligro quanto sea necessario»».

En otro orden de cosas, se recomendaba reunir materiales para la defensa: armas, municiones, pólvora y artillería, especialmente «de campo», que debía fundirse en el reino. Para almacenarlo todo, proponía «que se edifique una casa de muniçión». No eran provisiones muy diferentes de las que se habían adoptado treinta o cuarenta años antes; pero Mondéjar, al igual que Maqueda, las quería permanentes. Y justamente eso era lo que deseaba en el capítulo de la gente de guerra. Primero la caballería profesional, «la gente de a cavallo que ay en este Reyno que ganan sueldo», cuyo número había que «acreçentar». Según decía, los sesenta jinetes que había, divididos en cuatro compañías de quince hombres cada una, dos al norte y otras dos al sur de la ciudad de Valencia, eran pocos para las cincuenta leguas de costa del reino; y, sin embargo, hacían «tan gran fructo [...] que desde que el dicho Marqués entró en este Reyno hasta hoy, no an capturado los enemigos un solo hombre en tierra». Debía contarse con dos compañías en la ciudad de Valencia para acudir a los rebatos cercanos, lo cual, decía, «no puede suplirse [...] con la gente de a cavallo que ay en Valençia, porque es muy poca y apenas ay cavallero que tenga cavallo»; es más, «gente que no ganase sueldo, no puede salir a los rebatos con la presteza que se requiere». De similar opinión era con respecto a la infantería, pues veía «neçessario que stubiessen hechos dos mil infantes, y señalados capitanes y otros officiales para ellos»; no obstante, esta propuesta parece limitada a momentos de alarma, como la de fines de 1574; y, más que movilizados, lo que implicaría un enorme gasto, el virrey parece quererlos solo aprestados, acaso sin toda la paga, de forma que «pudiessen lebantarse con brevedad quando pareçiese que era menester para resistir a los enemigos», pero no para actuar solos, sino «juntamente con la gente de las çiudades, villas y lugares», la cual, por otro lado, «sin gente que ganasse sueldo, sería de poco effecto».

Las medidas de Mondéjar atañían tanto al viejo sistema defensivo, anclado en la sociedad valenciana (castillos, huestes, municipios), como a las novedades, muchas de las cuales, como la reunión de armas, la guardia de caballería o la formación de un ejército de infantería regular en momentos de alarma, ya habían sido ensayadas, con éxito variable, durante el largo virreinato del duque de Calabria (Pardo Molero, 2001, 205-409). Algunas, como las tropas de infantería o el desalojo de lugares mal defendidos, eran excepcionales, consecuencia de la alarma. Otras, sin embargo, ya eran o se querían ordinarias, permanentes. Y todas ellas dan fe del deseo de «refor- 
mar» la defensa, cuyos componentes, como miembros de un cuerpo bien gobernado, debían apoyarse unos a otros.

La preferencia de Felipe II por las galeras quedó olvidada en el memorial de Mondéjar. Tan solo se contemplaba la posibilidad de armar «un par de vergantines o fragatas para quando fuere neçessario dar algún aviso por mar a algún lugar de la marina o a la isla de Ybiza». Hábilmente, el virrey se centraba en las provisiones terrestres, que atraerían el interés de los estamentos. Tampoco se dedica una línea a los moriscos, pese a que la situación de la minoría preocupaba seriamente en la corte. Ciertos testimonios, aunque aislados y poco consistentes, extendían las sospechas habituales de colaboración entre moriscos, turcos y berberiscos (incluso protestantes). Nada apuntaba a una «alteración» general de la minoría, pero la preocupación se extendió: así, el Consejo de Inquisición se preguntaba si sería conveniente «quitar los moriscos de la costa de la mar». Consultados, los inquisidores de Valencia analizaron la cuestión con lógica escolástica. Según Rafael Benítez, consideraron, partiendo de lo más radical, que librarse por completo de la población morisca sería lo mejor «para la total y perpetua seguridad» del reino. Pero semejante solución sería catastrófica, especialmente para las rentas de instituciones y particulares del reino. De modo que apuntaron a una medida moderada: desplazar solo a los de la costa. Felipe II, que no deseaba molestar a los moriscos valencianos, volvió a consultar al vicecanciller Bolea, que recuperó sus propuestas de 1570. Finalmente, se descartó cualquier desplazamiento de los moriscos; pero, a cambio, el rey insistió en la necesidad de ocuparse de la defensa del reino, y de que los estamentos (tranquilizados con respecto a los moriscos) se comprometiesen en su financiación (Benítez Sánchez-Blanco, 2001, pp. 286-291).

Así, Mondéjar pudo jugar sus cartas: olvidar las galeras y cualquier traslado de los moriscos, y pedir colaboración para la defensa terrestre. Encajando sus propuestas en las preferencias de los estamentos, les arrancó la suma de cien mil libras, el mayor servicio hasta entonces fuera de cortes (Belchí Navarro, 2006, pp. 236-237). La alarma de aquel invierno explica en parte tan insólita decisión: sin duda el virrey manejó con habilidad digna de Maquiavelo la amenaza turca para lograr sus fines, pero la negociación y la reflexión colectiva canalizaron la urgencia defensiva hasta que coincidieron los intereses estamentales y las propuestas del virrey, propiciando una reforma de la defensa del reino que no alteraba su orden político.

Mendoza dejó el virreinato valenciano a principios de 1575. Le sustituyó Vespasiano Gonzaga, que llegó al reino aureolado por su fama de experto en fortificaciones (Belchí Navarro, 2006, pp. 58-59). Con el donativo estamental recién concedido, el nuevo virrey se puso manos a la obra en la mejora de la defensa. Pero, pasada la alarma, sus provisiones no revestirían la urgencia de algunas de las apuntadas por Mondéjar en 1574. A primeros de 1576 Gonzaga rindió cuentas a la corte de su tra- 
bajo en materia defensiva, tomando como base la relación de Mondéjar, anotando lo que se había hecho y lo que quedaba pendiente, y reflejando la diferencia entre una coyuntura extraordinaria y otra ordinaria. Gonzaga anotó que había llevado a cabo la visita de la costa, que el marqués había dejado incompleta; o que había puesto orden en las milicias locales, asignando destinos, ordenando reseñas y alardes, distribuyendo armas, etc. Y que se había ocupado personalmente de la revisión del sistema de custodia, acometida como una visita, «privando de officios a algunos, y criando otros de nuevo», pero haciéndolo todo por el procedimiento ordinario, es decir, «con acuerdo de los diez y ocho y conforme a la dispusiçión del fuero». Pero otras medidas las dejó en suspenso, al no verlas oportunas en ausencia de alarma: como apremiar a los alcaides a ocupar sus puestos y a tener la gente necesaria en sus castillos, en lo que anotó que «se hará a su tiempo»; o la compra de caballos por las personas de condición, que no debía hacerse a la ligera, «porque, sin urgente ocasión, formarían agravio dello». Finalmente, en lo relativo a la gente de sueldo, el virrey distinguía entre la caballería y la infantería: si coincidía en la necesidad de incrementar la primera, la medida propuesta por Mondéjar para la infantería, tener listos los dos mil infantes, debería reservarse para cuando hubiese aviso de la Armada otomana ${ }^{23}$.

Las provisiones de Gonzaga evidencian que, como sus predecesores, concebía el reino como un todo orgánico y articulado, cuyas partes debían auxiliarse unas a otras, de modo que hubiese correspondencia entre torres, fortalezas, soldados y municipios. Más que remover el orden constituido, el virrey trataba de reforzarlo, sin olvidar la diferencia entre lo que podía hacerse ante una urgente necesidad y lo que convenía en tiempo ordinario. Pero en 1577 volvió la alarma, en forma de amenazas de la Armada turca y presuntas conspiraciones moriscas. Como en ocasiones anteriores, se insistió en reforzar la defensa del reino, pero no por alarmismo. Una vez más, las opiniones del vicecanciller Bolea canalizaron el debate en la corte. El jurista aseguraba ordenar sus pensamientos «a ley de buen discurso y gobierno», lo que acaso pueda leerse como razón de estado (que no ignoraría), pero más parece apuntar a la razón natural. De hecho, sus recomendaciones no se apartaban del respeto al orden, como podía esperarse de un consejero letrado: seguía desechando los informes de complots, aunque no la preocupación que suscitaban, de modo que, en prevención de cualquier eventualidad, volvía a recomendar el refuerzo de la defensa, especial-

23 En este punto la anotación marginal de lo hecho por Gonzaga está incompleta por rotura del papel; puede leerse: «Esto convendría mucho que man [...] que serían pocos dos mil infantes [...] bastaría que por aora, no haviendo más aviso de armada, que se resolbiesse y los capitanes estubiessen a punto». Mi lectura es que convendría que lo mandase el rey, aunque dos mil serían pocos en caso de alarma, y que de momento se deje en suspenso (según las acepciones del Tesoro de Covarrubias del verbo resolver), salvo en lo relativo a los capitanes. AGS, Guerra y Marina, Guerra Antigua, leg. 81 , f. 38 , se anota en el sobrescrito que lo envía Gonzaga con carta de 17 de febrero de 1576 . Véanse ff. 35-37. 
mente en Valencia, consultando con el virrey (Benítez Sánchez-Blanco, 2001, pp. 297-299). Requerido por el rey, Gonzaga informó de todo el trabajo hecho en las torres y fortificaciones, en el sistema de avisos, en las huestes locales, etc. Y, aunque decía no creer en conspiraciones, recomendaba toda prudencia a fin de no inquietar a los moriscos, e insistía en aquello que aún podía mejorarse: la custodia y provisión de las fortalezas, el refuerzo de la caballería de la guardia de costa, especialmente la que dependía directamente de él; $y$, si bien rechazaba la entrada de tropas foráneas en el reino, aconsejaba tenerlas listas en las fronteras castellanas en los momentos de alarma. Finalmente, y al objeto de conseguir dinero, dado lo exhaustos que estaban los estamentos después de su reciente servicio, sugirió imponer una contribución a los lugares de moriscos, «pues son la causa deste desasosiego» (Benítez Sanchez-Blanco, 2001, pp. 302-305). Semejante razonamiento no era nuevo en Valencia, y aún menos en Granada (Pardo Molero, 2001, pp. 273-274; Jiménez Estrella, 2004, pp. $42-43,120)$. Aunque no respondía exactamente a los criterios fiscales inspirados por la teología moral, podía justificarse en función de la necesidad pública y de un concepto elemental de la justicia (Aliaga Girbés, 1973; Scordia, 2005). Como las otras reflexiones del virrey Gonzaga, era una aplicación de la razón natural a problemas de gobierno, sin necesidad de recurrir a la razón de estado.

\section{Las causas del desasosiego}

En aquellos años finales de la década de 1570, el jurista Tomás Cerdán de Tallada componía su primer tratado sobre el gobierno de la monarquía. Su trabajo como abogado de pobres y miserables de la ciudad de Valencia lo había puesto en contacto con la práctica judicial y penitenciaria, lo que se plasmó en su Visita de la cárcel, impresa en 1574 (Canet Aparisi, 2008, pp. 49-50). Pero sus inquietudes le llevaron a preocuparse por problemas mayores. En el Verdadero govierno desta Monarchía, publicado en Valencia en 1581, volcó, tanto o más que su experiencia, sus amplias lecturas. Siendo el objetivo de su obra «la conservación de la paz», afirma convencido que «la primera causa que impide la paz en la República christiana es no guardarse los mandamientos de Dios». Su compromiso con la caridad, que ejercía a diario en su oficio, debió pesar en tal afirmación, pero también otras razones. Su opinión se asienta en una panoplia de citas bíblicas, en concreto del Antiguo Testamento: Salmos, Proverbios, Reyes e Isaías le sirven para recordar las bienaventuranzas que esperan a los que cumplen la ley de Dios y que no habrá paz para los malvados. Pero también sazona su argumento con referencias históricas, como la pérdida de España, castigo decretado por Dios por el pecado del rey Rodrigo. La conjunción de historia sagrada e historia profana le lleva a actualizar el motivo y aplicarlo a su tiempo, para sostener 
que, «por los pecados de los hombres», Dios, además de enviar pestes, hambres y carestías, «toma vengança de nosotros por medio de Turcos y Bárbaros, enemigos de nuestra religión Christiana» (Cerdán de Tallada, 1581, ff. 52v-56v).

Justificaba esta afirmación no solo con la Biblia sino con el derecho canónico. Primero, el canon 10, distinción 56, del Libro I del Decretum Gratiani, que explica que los pecados de la carne atraen la perdición de las naciones, y que España, Provenza y Burgundia, «per ignorantiam legis Dei» ya estaban experimentando su castigo «per Sarracenos», a quienes Dios «venire et sevire permisit». Asimismo el jurista remitía al canon 47, primera cuestión de la causa VII, segunda parte del Decretum, que exhorta a los obispos a que, en la persecución, no abandonen su diócesis, sino que, frente a las insidias del enemigo, enviadas como castigo por nuestros pecados, dirijan y conforten a su grey ${ }^{24}$. Su otra fuente era el libro de Isaías, cuyo primer capítulo es mucho más contundente que los cánones acerca de la venganza divina sobre los pecadores.

Cerdán escribe poco antes de que arranque con toda virulencia la polémica antimaquiaveliana, cuando aún era posible una lectura del florentino sin los estigmas que pesarían sobre él desde los últimos años del siglo Xvi (Howard, 2011, p. 645). No es raro, pues, que cite con aprobación a Maquiavelo, y que lo haga a propósito de la unidad y preservación de la fe (Truman, 1999, p. 194; Canet, 2008, p. 120; Gandoulphe, 2008, pp. 170-171). Con todo, el estilo y el fondo de su argumentación están, en apariencia, en las antípodas del pensamiento de Furió Ceriol. ¿Cabría suponer que, entre el liberal ambiente de la Lovaina de mediados de siglo y el clima de oposición religiosa de la Valencia de 1580 la radicalización confesional ha afectado a los términos de la reflexión racional? Poner nuestra atención en las causas del mal, de aquel «desasosiego» al que se refería Gonzaga, puede orientarnos. Como vimos, el autor del Concejo estaba dispuesto a atribuir las derrotas militares a los pecados de los gobernantes, siempre que éstos no se entendiesen en un sentido convencionalmente religioso, sino más bien moral. Pero los males que evoca Cerdán no son tanto derrotas militares achacables a negligencias más o menos pecaminosas, sino calamidades y plagas, incluidos «Turcos y Bárbaros», difícilmente explicables al margen de la voluntad divina. En esto la autoridad de Isaías difícilmente podía despreciarse, y menos por Furió, que había insistido, en su tratado Bononia, en buscar en la Biblia el fundamento de la verdadera razón (Furió Ceriol, 1996, pp. 470-471). A mayor abundamiento, Cerdán no propone soluciones puramente piadosas como remedio de los males que denuncia, sino también seculares: en particular, reformar las leyes y la justicia para fomentar la concordia y aproximar así la realidad del

24 He identificado las referencias mediante los índices de Ochoa-Díez, 1964 (agradezco a la Profesora Teresa Canet que me facilitara una copia), y la Bibilioteca Digital del Munchener Digitalisierung Zentrum (https://www.digitale-sammlungen.de). 
gobierno al orden de inspiración divina (Truman, 1999, pp. 196-197; Canet Aparisi, 2008, pp. 129-149).

Para el todavía abogado de pobres y miserables, pronto promocionado a la abogacía fiscal del reino, la correspondencia entre los órdenes natural y divino era evidente, como queda patente desde las primeras páginas de su obra, de acento lulia$\mathrm{no}^{25}$. Esa misma correspondencia la hemos considerado implícita en algunos pasajes de Furió Ceriol, y también se adivina en el trabajo de los hombres del rey: en las peticiones y provisiones de Maqueda y Mondéjar para tener el reino «en orden», en las observaciones de Antonelli o Gonzaga, empeñados en completar con razonado artificio la obra de la naturaleza, y en la prudencia política del vicecanciller Bolea, que ponderaba el valor de la información y la situación real de los reinos. No por razonar en términos humanos, ni por estar más o menos familiarizado con la obra de Maquiavelo o con la razón de estado, se perdía de vista la trascendencia de las consideraciones morales. A tenor de aquel orden del mundo podían establecerse culpas genéricas para los males que lo aquejaban, pero también responsabilidades concretas, operando sobre las cuales cabía restablecerse algo del orden alterado. Este tipo de convicciones, compartidas entre la oficialidad de la monarquía, hacía posible su administración con una razón que podía ser política sin dejar de ser moral.

Las medidas adoptadas para mejorar la defensa eran resultado de cálculos políticos, reflexiones y debates en los que se razonaba sobre cómo atender a las necesidades sin alterar el orden de cada territorio. Por eso, la intensificación de la administración militar no puede interpretarse como un producto, sin más, de las amenazas bélicas, ni tampoco como resultado de manipular los ánimos para imponer un refuerzo del poder real. El panorama se complicaba al incorporar elementos de creciente sofisticación: el debate se teñía de conceptos técnicos, en lo militar para mantener y actualizar los nuevos componentes de la defensa; y también en lo político, al insistirse cada vez más en la razón de gobierno y adoptarse conceptos entendidos como específicos de la política. Pero esto no implicó necesariamente secularización. En vísperas de la guerra sin cuartel contra el maquiavelismo, la reflexión y la práctica políticas se reforzaban mutuamente en su afán por mejorar el orden; pero el fundamento de ese orden seguía siendo trascendente.

25 A la influencia de Lull, acaso transmitida por la obra del jurista tolosano Pierre Grégoire, me refiero en Pardo Molero (2014, pp. 402-403); Truman insiste en el afán de unidad y armonía de Cerdán, comparándolo con una escena de Troilo y Crésida, de Shakespeare (1999, pp. 196-197). 


\section{AGRADECIMIENTOS}

Este trabajo forma parte de los proyectos «Privilegio, trabajo y conflictividad. La sociedad moderna de los territorios hispánicos del Mediterráneo occidental entre el cambio y las resistencias», ref. PGC2018-094150-B-C21, Ministerio de Ciencia e Innovación, y PURE: Public Renaissance: Urban Cultures of Public Space between Early Modern Europe and the Present (HERA-net, 2019-2022; PCI2019-103749). La edición de este trabajo ha sido posible gracias a la ayuda del Programa de Grupos de Potencial Crecemento concedida por la Consellería de Cultura, Educación e Universidade da Xunta de Galicia al GI-1921 de la USC (Referencia: GPC, ED 431B 2021/06). 


\section{Bibliografía}

Albonico, Simone (2015), «La prima redazione della 'Orazione scritta a Carlo V' di Giovanni della Casa», Filologia Italiana, 12, pp. 79-119.

Aliaga Girbés, José (1972), Los tributos e impuestos valencianos en el siglo XVI. Su justicia y moralidad según Fr. Miguel Bartolomé Salón (1539?-1621), Roma, Instituto Español de Historia Eclesiástica.

Álvarez García, Héctor (2016), «Fadrique Furió Ceriol: el precursor del Estado laico en España», Revista de Derecho UNED, 18, pp. 659-682. <https://doi. org/10.5944/rduned.18.2016.16900>.

Bataillon, Marcel (1966), Erasmo y España. Estudios sobre la historia espiritual del siglo XVI, Madrid, Fondo de Cultura Económica.

Belchí Navarro, Peligros (2006), Felipe II y el virreinato valenciano (1567-1578). La apuesta por la eficacia gubernativa, Valencia, Biblioteca Valenciana.

Benítez Sánchez-Blanco, Rafael (1998), «Don Bernardo de Bolea y los proyectos de deportación de los moriscos valencianos», en Martínez Millán, José (dir.), Felipe II (1527-1598). Europa y la monarquía católica, Madrid, Parteluz, vol. 3, pp. 89-110.

Benítez Sánchez-Blanco, Rafael (2001), Heroicas decisiones. La Monarquía Católica y los moriscos valencianos, Valencia, Institució Alfons el Magnànim,

Berlin, Isaiah (1981), Against the Current. Essays in the History of Ideas, Oxford, Oxford University Press.

Bernabé Gil, David (1990), Monarquía y patriciado urbano en Orihuela, 1445 1707, Alicante, Caja de Ahorros Provincial de Alicante.

Bertomeu Masiá, María José (2009), La guerra secreta de Carlos V contra el Papa. La cuestión de Parma y Piacenza en la correspondencia del cardenal Granvela, Valencia, PUV-Editum.

Borra Mahiques, Josep Vicent (1992), «Geografia i control del territori. El coneixement i la defensa del litoral valencià al segle XVI: l'enginyer Joan Baptista Antonelli», Cuadernos de Geografía, 52, pp. 183-199.

CÁmara Muñoz, Alicia (1989), «Fortificación, ciudad y defensa de los reinos peninsulares en la España imperial. Siglos XVI y XVII», en De Seta, Cesare y Le Goff, Jacques (eds.), La ciudad y las murallas, Madrid, Cátedra, pp. 89-96.

CAnet Aparisi, Teresa (2008), Vivir y pensar la política en una Monarquía plural. Tomás Cerdán de Tallada, Valencia, PUV. 
Catalá Sanz, Jorge - Urzainqui Sánchez, Sergio (2009), La conjura morisca de 1570: la tentativa de alzamiento en Valencia, Valencia, Biblioteca Valenciana.

Cerdán de Tallada, Tomás (1581), Verdadero govierno desta Monarchía tomado por su proprio subjecto, la conservación de la paz, Valencia, Viuda de Pedro de Huete.

De Mattei, Rodolfo (1958), «Carlos V, la razón de estado y Monseñor Della Casa», Cuadernos Hispanoamericanos, 107-108, pp. 211-218.

De Mattei, Rodolfo (1958), Il problema della «ragion di stato» nell'età della Controriforma, Milán y Nápoles, Riccardo Ricciardi Editore.

Escribano PÁez, José Miguel (2015), El coste de la defensa. Administración y financiación militar en Navarra durante la primera mitad del siglo XVI, Pamplona, Gobierno de Navarra.

FAVARÒ, Valentina (2009), La modernizzazione militare nella Sicilia di Filippo II, Palermo, Associazione Mediterranea.

Fernández Álvarez, Manuel (dir., 2003), Corpus documental de Carlos V, 5 vols., Madrid, Espasa Calpe.

Fox Morcillo, Sebastián (1556), De regni regisque institutione, libri III, Amberes, Gerardum Spelmannum.

Furió Ceriol, Fadrique (1996), Obra completa, edición a cargo de Henry Méchoulan y Jordi Pérez Durà, Valencia, Alfons el Magnànim-Generalitat Valenciana, vol. 1.

Gandoulphe, Pascal (2008), «Trayectoria de la tratadística política y jurídica valenciana: Tomás Cerdán de Tallada, del Verdadero gobierno (1581) al Veriloquium en reglas de estado (1604)», en Aranda Pérez, Francisco José y Rodrigues, José Damião, De Re Publica Hispaniae. Una vindicación de la cultura política en los reinos ibéricos en la primera modernidad, Madrid, Sílex, pp. 149-186.

García Álvarez, Héctor (2016), «Fadrique Furió Ceriol: el precursor del Estado laico en España», Revista de Derecho (18), pp. 659-682.

García Bourrellier, Rocío (2018), «Bernardino de Cárdenas y Pacheco», en Diccionario biográfico español, edición electrónica, Madrid, Real Academia de la Historia <http://dbe.rah.es/biografias/20181/bernardino-de-cardenas-y-pacheco>.

García Pinilla, Ignacio J. (2003), «La estructura de Bononia de Fadrique Furió Ceriol», en Grau Codina, Ferran, Gómez Font, Xavier, Pérez Durà, Jordi y Estellés González, José María (coords.), La Universitat de València i l'Humanisme: Studia humanitatis i renovació cultural al Nou Món, Valencia, Universitat de València, pp. 453-462. 
Gil Pujol, Xavier (2016), La fábrica de la Monarquía. Traza y conservación de la Monarquía de España de los Reyes Católicos a los Austrias, Madrid, Real Academia de la Historia.

Guevara, Antonio de (1850), Epístolas familiares, edición a cargo de Eugenio de Ochoa, Madrid, M. Rivadeneyra.

Guevara, Antonio de (1994 [1531]), Relox de príncipes, edición a cargo de Emilio Blanco, Madrid, ABL Editor-Conferencia de Ministros Provinciales de España.

Hernando SÁnchez, Carlos José (1994), Castilla y Nápoles en el siglo XVI. El virrey Pedro de Toledo. Linaje, estado y cultura, Valladolid, Junta de Castilla y Léon.

Hernando SÁnchez, Carlos José (ed., 2000), Las fortificaciones de Carlos V, Madrid, Sociedad Estatal para la Conmemoración de los Centenarios de Felipe II y Carlos V.

Hespanha, António Manuel (2002), Cultura jurídica europea. Sintesis de un milenio, Madrid, Tecnos.

HowARD, Keith David (2011), «Fadrique Furió Ceriol's Machiavellian vocabulary of contingency», Renaissance Studies, 26, pp. 641-657. <https://doi.org/10.1111 /j.1477-4658.2011.00762.x>.

HowARD, Keith David (2014), The Reception of Machiavelli in Early Modern Spain, Woodbridge, Tamesis.

Jiménez Estrella, Antonio (2004), Poder, ejército y gobierno en el siglo XVI. La Capitanía General del Reino de Granada y sus agentes, Granada, Universidad de Granada.

JouAnna, Arlette (2013), La pouvoir absolu. Naissancede l'imaginaire politique de la royauté, París, Gallimard. <https://doi.org/10.14375/NP.9782070120475>.

Kantorowicz, Ernst H. (1957), The King's Two Bodies. A Study in Medieval Political Theology, Princeton, Princeton University Press.

Lisón Tolosana, Carmelo (1991), La imagen del Rey. Monarquía, realeza y poder ritual en la Casa de los Austrias, Madrid, Espasa Calpe.

Lorite Martínez, María Isabel (2017), Las juntas del Estamento Militar valenciano, 1588-1598, Castellón, SACE.

Lovejoy, Arthur (1966), The Great Chain of Being. A Study of the History of one Idea, Cambridge, Harvard University Press.

Machiavelli, Niccolò (1989), Tutte le opere, ed. de Mario Martelli, Florencia, Sansoni.

Maravall Casesnoves, José Antonio (1972), Estado moderno y mentalidad social (siglos XV al XVII), 2 vols., Madrid, Revista de Occidente. 
Maravall Casesnoves, José Antonio (1986), Antiguos y modernos. Visión de la historia e idea del progreso hasta el Renacimiento, Madrid, Alianza Editorial.

Maravall Casesnoves, José Antonio (1975), Estudios de historia del pensamiento español. Serie tercera. Siglo XVII, Madrid, Ediciones Cultura Hispánica.

Méchoulan, Henry (1978), Razón y alteridad en Fadrique Furió Ceriol, Madrid, Editora Nacional.

Méchoulan, Henry (1996), «Introducción» a Fadrique Furió Ceriol, El Concejo y consejeros del príncipe, en Obra completa, Valencia, Alfons el Magnànim-Generalitat Valenciana, vol. 1, pp. 47-76.

Najemi, John M. (ed.) (2010), The Cambridge Companion to Machiavelli, Cambridge, Cambridge University Press. < https://doi.org/10.1017/ CCOL9780521861250>.

OAKLEY, Francis (1984), Omnipotence, Covenant and Order. An Excursion in The History of Ideas from Abelard to Lebniz, Ithaca y Londres, Cornell University Press.

OAKLey, Francis (2015), The Watershed of Modern Politics. Law, Virtue and Consent (1350-1650), New Haven y Londres, Yale University Press, 2015.

OchoA, Xavier y DíEz, Aloisio (1964), Indices canonum, titulorum et capitulorum Corporis Iuris Canonici, Roma, Commentarium Pro Religiosis.

Pardo Molero, Juan Francisco (2001), La defensa del imperio. Carlos V, Valencia y el Mediterráneo, Madrid, Sociedad Estatal para la Conmemoración de los Centenarios de Felipe II y Carlos V.

PARdo Molero, Juan Francisco (2006), «Dos informes del siglo XVI sobre la guardia de costa del Reino de Granada», Chronica Nova. Revista de Historia Moderna de la Universidad de Granada, 32, pp. 233-249.

PArdo Molero, Juan Francisco (2017), «Honor, soldados y castillos. Constitución y defensa en la Monarquía Hispánica en el siglo XVI», en García Hernán, Enrique y Maffi, Davide (eds.), Estudios sobre guerra y sociedad en la Monarquía Hispánica. Guerra marítima, estrategia, organización y cultura militar (15001700), Valencia, Albatros, pp. 785-801.

Pardo Molero, Juan Francisco (2014), «Los usos de Roma. Ideas y recursos políticos en la Monarquía Hispánica», en Dubouloz, Julien, Pittia, Silvia y Sabatini, Gaetano (eds.), L'imperium Romanum en perspective. Les savoirs d'empire dans la République romaine et leur heritage dans l'Europe médiévale et moderne, Besançon, Presses Universitaires du Franche-Comté, pp. 389-409.

Puigdomènech Forcada, Helena (1988), Maquiavelo en España. Presencia de sus obras en los siglos XVI y XVII, Madrid, Fundación Universitaria Española. 
Piles Almela, María Antonia (1981-1982), «El virreinato interino de D. Joan Llorens de Vilarrasa», Estudis. Revista de Historia Moderna, 9, pp. 243-266.

Quaglioni, Diego (2011), Machiavelli e la lingua della giurisprudenza. Una letteratura della crisi, Bolonia, Il Mulino.

Reglá Camipistol, Joan (2000), Felipe II y Cataluña, Madrid, Sociedad Estatal para la Conmemoración de los Centenarios de Felipe II y Carlos V.

Rodríguez Raso, Rafaela (1963), Maximiliano de Austria, gobernador de Carlos $V$ en España. Cartas al emperador, Madrid, Escuela de Historia Moderna.

SAlvador Esteban, Emilia (1974), Cortes valencianas de Felipe II, Valencia, Universidad de Valencia.

Salvador Esteban, Emilia (1987), Felipe II y los moriscos valencianos. Las repercusiones de la revuelta granadina (1568-1570), Valladolid, Universidad de Valladolid.

Salvador Lizondo, María Dolores (1986), Los virreinatos de los duques de Maqueda $y$ de Segorbe (1553-1563). Configuración del bandolerismo: presión islámica y problemática de su gobierno, Universitat de València, [Tesis doctoral inédita].

Senellart, Michel (1995), Les arts de gouverner. Du regimen médiéval au concept de gouvernement, París. Editions du Seuil.

SCORDIA, Ludwyne (2005), "Le roi doit vivre du sien». La théorie de l'impôt en France (XIIIe-XVe siècles), París, Institut d’Études Augustiniennes.

Truman, Ronald W. (1999), Spanish Treatises on Government, Society and Religion in the Time of Philip II. The de regimine principum and Associated Traditions, Leiden, Brill. < https://doi.org/10.1163/9789004247499>.

VIroli, Maurizio (2009), De la política a la razón de Estado. La adquisición y transformación del lenguaje político (1250-1600), Madrid, Akal.

Zuckert, Catherine H. (2017), Machiavelli's Politics, Chicago y Londres, The Univesity of Chicago Press. 